\title{
Jenkin's Lingua Franca Core and Autistic Children's EFL Speech Sound Production
}

\author{
Rida Wahyuningrum \\ Deparment of English Education \\ Faculty of Language and Science University of Wijaya Kusuma Surabaya \\ Dukuh Kupang XXV/54 Surabaya, Indonesia \\ ridawahyuningrum@gmail.com
}

\begin{abstract}
This paper is trying to give a description of autistic children's EFL speech intelligibility in terms of segmental sound production viewed from Lingua Franca Core proposed by Jennifer Jenkins as published in her book entitled The Phonology of English as an International Language (2009). It was the modification of Bryan Jenner's the Common Core, a list of features of English pronunciation he considered essential for intelligibility anywhere in the world. It was a case study that employed two autistic children (aged eight and nine) learning their EFL in formal environment (schools and autism therapy centre). This descriptive-qualitative study reported that five out of nine aspects of EFL speech production by the two autistic children indicated the shortcomings of them. Those five aspects covered consonantal inventory, phonetic requirements, consonant clusters, vowel quantity, and nuclear stress. The drawbacks of those five aspects, however, could still be considered as to lead the way to intelligible speech with some notes upon their quality.
\end{abstract}

Keywords-EFL speech sounds, speech intelligibility, autistic children

\section{INTRODUCTION}

Living in a world of both bilingualism or multilingualisn as today, autistic children seem to have a challenge. These have severe language deficits and socialization problems. Concerning language acquisition, autistic children can learn and use their language despite qualitative impairments in communication. Specifically, it is a kind of primary impairments in pragmatic aspects of language (American Psychiatric Association, 1994; Belkadi, 2006, pp. 3-13). It was once believed that parents saw no positive effects for their autistic chilren towards learning a language other than their first language. Some believe that such a second or additional language might harm the process of language acquisition. Hughes (2011) reported that bilingualism doesn't impair language skills in autistic children. Kremer-Sadlik (2005) found out that autistic children would have no problems in producing speech sounds of more than one language. The study reported that English is recommended to be learnt by autistic children in respect to its consistency and simplicity. Genesee (2009), too, recommended that autistic children have the same opportunity as that of normal children in learning their second language. These children can acquire functional competence in two languages at the same time, within the limits of their impairment.
However, some studies upon autistic children's language production showed some specific charactreristics of the language they produced. Rahayu (2014), for example, mentioned one-way communication as referring to her autistic subject's capability of interactional communicationin using bahasa Indonesia. This is the same with what Indah (2006) discovered about their language characteristic, namely their sentences were found as to echolalia, repeated sentences without referring to any relevant context over and over again. Meanwhile, Alwiyanti (2005) pointed out incompleteness of her eight-year-old autistic subject's speech at clause/sentence level and Dewi (2014), too, reported similar results. She noted several obstacles her subject had in terms of the fluency of his utterances. They included consonant articulation, speaking with short words, inability to communicate and give information, and difficulties with long sentence production. Furthermore, Indah (2006) reported that the artculation of such children is commonly clear enough despite some various lapses in pronouncing the objects. They are often found to do a kind of substituting, for example saying one for another thing. Deletion is also another kind which is found in how they say things by omitting one or two syllables of the word, or they even add more syllables. Flat intonation and misleading stresses also characterise their language, too.

By referring to the findings of the previous studies above, in terms of communication, autistic children learning their English as a foreign language (henceforth EFL) are supposed to deliver meanings or messages represented from how they produce the language. Consequently, in communicating meanings or messages, it is important to consider the presence of meaningful sounds. Meaningful sounds are produced in such a way that it has clarity, resonance, stability, and the control of adequate breath support, appropriate pitch level, and diction (Wells, 2004, p. 1). The speech sounds which are produced as having the qualities above will bring about the quality of being easily understood or clear to the mind. In other words, the speech sounds produced are intelligible.

However, the purpose of learning English today is more of using it in communication with other 'non-native' speakers as an international language rather than as a foreign language. It is called English as Lingua Franca (ELF). Such situation requires, of course, the mutual intelligibility. It has been an agreement that native speaker accent is used as norm (read: correctness) to fulfill such intelligibility. However, native 
speaker accent is supposed to be somewhat of a point of reference, a 'model' for guidance and approximation (Spicer, 2011).

Jenkins (2009) redefined and reclassified pronunciation errors. In doing so, she considered some sociolinguistics factors of regional variation. In this way, English learners are allowed to use English to their own legitimate regional accents. In other words, there is no strong demand for EFL teachers to refer to native speaker pronunciation so that regarding some deviations as errors.

In relation with the EFL speech production of autistic children, this paper is trying to give a description of autistic children's EFL speech intelligibility in terms of segmental sound production viewed from Lingua Franca Core.

\section{LITERATURE REVIEW}

\section{A. Second Language Acquisition and Autistic Children}

Autism concerns three impaired areas of functioning. One is language. This type of children have deficits in language use and pragmatics. Next is sociability. These children have difficulties in the recognition of others' intentions, beliefs, thoughts, knowledge states, and feelings. Also, they may struggle to create and sustain personal relationships and friendships. Then, these children have problems with imagination. They lack of pretend play and problems of 'decoupling' of an object from his function to pretend it is something else or a word from its literal meanings to understand non literal meanings (Kremer-Sadlik and Tamar, 2005).

Since autistic children are categorized into children with speech disorder or children with language impairment, some studies point out to the facts that there have not yet been found any negative effects of bilingualism upon them. Children with specific language impairment (SLI) learning two languages at the same time do not demonstrate any greater difficulties in their two languages, as compared to monolingual children with SLI. Another, a study comparing children with Down Syndrome being raised in bilingual homes with monolingual children with Down syndrome found that the bilingual children performed at least as well as the monolingual children with Down Syndrome (in their dominant language or language of greater exposure). Therefore, negative effects of bilingualism were not found. Finally, the vocabularies of English-Chinese bilingual and monolingual autistic children were compared in a study. The authors concluded that bilingualism did not have a negative effect on the children's language development, as both groups had similar vocabulary scores.

Based on what is described above, it is true that children with language impairments, including autistic children, have the same opportunity as that of normal children in learning their second language.

\section{B. Lingua Franca Core and Speech Intelligibility}

Intelligible speech produced between the native speakers of English is of course different from that of between the native speaker and EFL learners or among EFL learners themselves. For EFL learners, the clarity of message being conveyed has something to do with some difficulties of English pronunciation.

The fact that speakers have a mental representation of what they say, and that this can be different from what they actually do when they speak, shows us that speakers do not memorize every aspect of speech sound production. This is the matter of the relationship between the Mind and the Mouth. These rules are to describe the relationship between the Mind and Mouth : Speaker's Mind $\rightarrow$ Speaker's Mouth $\rightarrow$ Listener's Ear $\rightarrow$ Listener's Mind. For example, an EFL learner (speaker's mind) thought he has already produced the 'correct' sounds (speaker's mouth) of RP English. However, the sounds are heard different or they may fail to be observed as RP English (listener's ear) and as a result the sounds do not reveal intelligible sounds (listener's mind).

The term intelligibility in this study is a matter of the match between the intention of the subjects speaking their EFL and the response of the listener at the level of the understandability of speech. The description of sounds which were categorized into completely intelligible provides some characteristics, such as being understandable, matched (between speaker and listener), and communicative.

In relation with EFL speech intelligibility, Lingua Franca Core was presented by Jennifer Jenkins (2009) and it is the modification of Jenner's the Common Core (a list of the features of English pronunciation Bryan Jenner considered essential for intelligibility anywhere in the world), in order to take the reality of fully English as International Language into account (Walker, 2001, p. 2). Jenkin's modification identifies 7 areas in which it is essential to eliminate error in students' pronunciation: vowel quantity, consonant conflations, phonetic realizations, consonant cluster simplification, prominence and weak forms, tone groups, and nuclear/contrastive stress but not tone.

First, vowel quantity measures The length differences between the vowels of English feature in all accents. The long English vowels are very long in comparison with average vowel length in other languages. Because of this, the distinction between long and short vowels is more important than exact vowel quality, and should be clear in speech.

Second, consonant conflation is when a consonant of English does not occur in a learner's mother tongue, the 'missing' sound is substituted with something similar from the speaker's first language. However, this can cause serious confusion for both native speaker and non-native speaker listeners.

Third, phonetic realization is when the learner is struggling to pronounce English and he is using the sounds from his mother tongue that is close to the required English sounds. However, some such approximations may lead to unintelligibility.

Fourth, consonant cluster simplification happens when a learner employs either deleting or inserting one of the consonants to simplify a cluster. This, however, may affect intelligibility. 
Fifth, prominence and weak forms play an important role in producing the English speech. Due to this, teaching should focus on achieving adequate prominence on the stressed syllable, rather than on attaining perfect weak forms or schwas for the reduced vowels. With correct prominence, even if totally lacking in weak forms or schwa, a learner's English will be intelligible.

Sixth, tone group is the condition in which the learners may fail to use tone groups to divide the stream of speech into meaningful chunks. This may lead to a serious effect on intelligibility, too.

Seventh, nuclear/contrastive stress but not tone refers to putting the main stress on the wrong word in an utterance will direct the listener's attention to the wrong place, leading to confusion. However, for those many groups of languages displaying mutual intelligibility, namely, those, usually genetically related languages, similar to each other in grammar, vocabulary, pronunciation, or other features, speakers of one language usually find it relatively easy to achieve some degree of understanding in the related language.

\section{METHOD}

This study is descriptive and qualitative in nature. It was a case study that employed two autistic children (aged eight and nine) learning their EFL in formal environment (schools and autism theurapic centre). Both subjects were indicated as having autistic disorder, one among other types of Autism Spectrum Disorder/Pervasive Developmental Disorder (ASD/PDD).

\section{A. Data Collection}

The data collection is done through both participant observation and non participant observation. Besides, elicitation is performed together with the observation technique. Interview is also applied.

First, the subjects' voice taken from informal conversation was taped. In taking these data the researcher would be using some kinds of observation format and field notes. Also, the use of some media such realias or pictures were recommended when they were necessary, especially in the act of elicitation. Second, the taped voice went for transcription process. Finally, the accumulated data gathered from the three subjects would be documented and classified into different kinds of file format, for example S1 Data Collection.

\section{B. Data Collecting Tools}

Data collecting tools in this study included an MP3 recorder, SONY mp3 sound recorder.

\section{Data Transciption}

The audio-taped raw data were transcribed into data transcription sheets. Some utterances spotted as EFL segmental sounds in question would be transcribed in the form of phonetic transcription. The transcription referred to the IPA (International Phonetic Association). Later, the transcription developed into classification of segmental sounds of each subject by grouping them into word, phrase, and sentence level. This classification would help the researcher to see what sounds the subjects had already been able to produce in their EFL.

\section{Data Analysis}

The researcher analysed the intelligibility of autistic children's EFL speech by using tables or diagrams. This system helped the researcher control the data systematically. Tables were used to classify and identify the data which were inquired to answer problems as stated in the research question. For example, the subjects' speech production was classified into some tables of analysis, such as the classification of subject's utterances in word level, phrase level, and clause/sentence level. The conclusion was drawn based on the findings after the activities of data analysis procedure were completed.

\section{RESULT AND DISCUSSION}

Referring to Jenkin's Lingua Franca Core (2005), there are 5 out of 7 aspects of pronunciation to be considered with regard to the subjects' EFL intelligibility.

\section{A. Consonant Conflations}

The subjects had various classification of the consonantal inventory. Consonant deletion seemed to lead in number for the details of the inventory. It was noted that there were 9 points of deleted English consonants when producing the words. However, S1 did not delete as many consonants as S1 did. This will lead to a situation in which S2's consonant production was not that decent as that of S1's, despite his action of adding some consonants too. Another is consonant substitution. Both subjects were discovered to substitute some obstruent sounds. It happened because such sounds seemed to be their obstacles. In order to keep up with such sound production, they commonly substituted them with some which were closely-related to their existing sounds of their mother tongue. For example, it was often seen they substituted sounds $/ 3 /$ and $/ \int /$ with other sounds, prominently with sound /s/.

Next, consonant devoicing was also spotted as some fricatives and stops like $/ \mathrm{z} /, / \mathrm{v} /$, and $/ \mathrm{d} /$ were pronounced as $/ \mathrm{s} /, / \mathrm{f} /$, and $/ \mathrm{t} /$ at the word level. In terms of intelligibility, this action of devoicing did not affect too significantly the breaking down of EFL communication as seen in the examples "rose", "outside", and "arrive".

The sound /r/ production, finally, of both subjects were also considered intelligible since their being added in the final position and their being intensified either in the final or medial positions might refer to EFL targets, namely rhotic /r/.

\section{TABLE I. CONSONANT CONFLATIONS}

\begin{tabular}{|c|c|c|c|}
\hline Classification & S1 & $S 2$ & Examples \\
\hline Consonant Substitution & & & $/ \mathrm{la}: \mathrm{f} / \rightarrow$ [la:k] \\
\hline$/ \mathrm{f} / \rightarrow[\mathrm{k}]$ & $x$ & 1 & $/ \theta$ a $z z n d / \rightarrow[$ taøsn $]$ \\
\hline$/ \theta / \rightarrow[t]$ & 1 & 3 & /bri:ð/ $\rightarrow$ [bret] \\
\hline$/ ð / \rightarrow[\mathrm{t}]$ & 1 & $X$ & $/ \mathrm{m} \oslash[\mathrm{i}: \mathrm{n} / \rightarrow$ [meti:n] \\
\hline$/ \int / \rightarrow[t]$ & $x$ & 1 & $/ \int \delta g \partial(\mathrm{r}) / \rightarrow[\operatorname{s\sigma gg} \partial(\mathrm{r})]$ \\
\hline$/ \mathrm{J} / \rightarrow[\mathrm{s}]$ & $x$ & 3 & $/$ televizn $/ \rightarrow$ [televisn] \\
\hline$/ 3 / \rightarrow[s]$ & 5 & 2 & $/$ kærəts/ $\rightarrow$ [kerjats] \\
\hline
\end{tabular}




\begin{tabular}{|c|c|c|c|}
\hline Classification & $S 1$ & $S 2$ & Examples \\
\hline$/ \mathrm{r} / \rightarrow[\mathrm{j}]$ & $x$ & 1 & \\
\hline $\begin{array}{l}\text { Consonant Devoicing } \\
/ \mathrm{z} / \rightarrow[\mathrm{s}] \\
/ \mathrm{d} / \rightarrow \mathrm{t}] \\
/ \mathrm{v} / \rightarrow[\mathrm{f}]\end{array}$ & $\begin{array}{l}2 \\
2 \\
4\end{array}$ & $\begin{array}{l}3 \\
2 \\
5\end{array}$ & $\begin{array}{l}/ \mathrm{r} \circlearrowright \widetilde{z} / \rightarrow[\mathrm{r \partial \sigma s}] \\
/ \partial f r e I d / \rightarrow \text { [əfreIt }] \\
/ \text { væn } / \rightarrow[\text { fæn }]\end{array}$ \\
\hline $\begin{array}{l}\text { Consonant Addition } \\
\mathrm{r} \text { addition }\end{array}$ & 5 & 4 & /wعə/ $\rightarrow$ [wعər] \\
\hline $\begin{array}{l}\text { Consonant Deletion } \\
\mathrm{r} \text { deletion } \\
\mathrm{t} \text { deletion } \\
\mathrm{g} \text { deletion } \\
\theta \text { deletion } \\
\mathrm{j} \text { deletion } \\
\text { d deletion } \\
\mathrm{k} \text { deletion } \\
\mathrm{s} \text { deletion } \\
\mathrm{z} \text { deletion }\end{array}$ & $\begin{array}{l}x \\
1 \\
3 \\
x \\
x \\
5 \\
1 \\
x \\
x\end{array}$ & $\begin{array}{l}1 \\
X \\
3 \\
1 \\
1 \\
5 \\
1 \\
2 \\
1\end{array}$ & 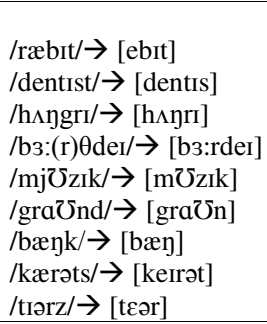 \\
\hline $\begin{array}{l}\text { Consonant Intensified } \\
\mathrm{r} \text { intensified }\end{array}$ & 2 & 9 & $/$ wintə(r)/ $\rightarrow$ [wintərr] \\
\hline Cluster Reduction & $x$ & 1 & /əkwعərıəs/ $\rightarrow$ [kv:rıəs] \\
\hline
\end{tabular}

\section{B. Phonetic Realization}

Both subjects were found to be capable of pronouncing some aspirated sounds, especially $/ \mathrm{p}^{\mathrm{h}} /, / \mathrm{t}^{\mathrm{h}} /$, and $/ \mathrm{k}^{\mathrm{h}} /$ in their initial position although not all of them. The following table explains the subjects' capability of pronouncing such sounds despite S2's flaw in producing $/ \mathrm{t}^{\mathrm{h}} /$ in initial position of word.

TABLE II. PHONETIC REALIZATION

\begin{tabular}{|c|c|c|c|}
\hline Classification & $S 1$ & $S 2$ & Examples \\
\hline $\begin{array}{l}\text { Aspirated } / \mathrm{p}^{\mathrm{h}} / \text { in the initial } \\
\text { position of word }\end{array}$ & 4 & 2 & {$\left[\mathrm{p}^{\mathrm{h}} \mathrm{Ikf} ə\right],\left[\mathrm{p}^{\mathrm{h}} \mathrm{erp} \partial\right],\left[\mathrm{p}^{\mathrm{h}} \mathrm{leI}\right]$} \\
\hline $\begin{array}{l}\text { Aspirated } / \mathrm{t}^{\mathrm{h}} / \text { in the initial } \\
\text { positin of word }\end{array}$ & 3 & $x$ & {$\left[\mathrm{t}^{\mathrm{h} e n}\right],\left[\mathrm{t}^{\mathrm{h}} \mathrm{aIm}\right],\left[\mathrm{t}^{\mathrm{h}} \mathrm{erbl}\right]$} \\
\hline $\begin{array}{l}\text { Aspirated } / \mathrm{k}^{\mathrm{h}} / \text { in the initial } \\
\text { position of word }\end{array}$ & 4 & 1 & {$\left[\mathrm{k}^{\mathrm{h}} \partial \circlearrowright \mathrm{t}\right],\left[\mathrm{k}^{\mathrm{h}} \mathrm{r} f \mathrm{n}\right],\left[\mathrm{k}^{\mathrm{h}} \mathrm{i}:\right]$} \\
\hline
\end{tabular}

\section{Consonant Cluster Simplification}

Looking into Table 4.35, pronouncing English clusters seemed to be not easy for S2. He often deleted one segment of the cluster member. For example he did not pronounce segment $/ \mathrm{k} /$ in a cluster $/ \mathrm{kw} /$ as seen in "quiet". However, both subjects deleted one segment /g/ in cluster $/ \mathrm{ng} /$ as in "English", "hungry", and "angry".

\section{TABLE III. CONSONANT CLUSTER SIMPLIFICATION}

\begin{tabular}{|c|c|c|c|}
\hline Classification & $S 1$ & $S 2$ & Examples \\
\hline Deleted sound $\mathrm{g}$ of cluster $\mathrm{ng}$ & 3 & 3 & 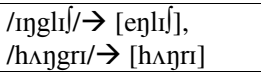 \\
\hline Deleted sound $\mathrm{w}$ of cluster $\mathrm{kw}$ & $x$ & 1 & /əkweərıəs/ $\rightarrow$ [kv:rıəs] \\
\hline Deleted sound $\mathrm{k}$ of cluster $\mathrm{kw}$ & $x$ & 1 & $/ \mathrm{kwaI \partial t} / \rightarrow$ [waiət] \\
\hline
\end{tabular}

Despite the faulty the subjects made in pronouncing English clusters $/ \mathrm{kw} /$ and $/ \mathrm{ng} /$, their pronunciation of the words belonging to latter cluster was considered intelligible enough for it did not cause any breakdown in communication. Unfortunately, the one which was referred to the previous cluster seemed to harm the intelligibility of the speech. It might be resulting in uncommunicativeness.

\section{Vowel Quantity}

Vowel quantity is described as that which was related to vowel length in speech production. It's simply about a longshort contrast of the vowels produced. Since long English vowels are very long in comparison with average vowel length in other languages, the distinction between long and short vowels is considered to be significant. Clear speech production will help describe the vowel quantity so that meaning can be grasped to understanding.

All subjects did not have any problems producing either long or short English vowels. As noted in the following table, the only flaw but insignificant fact about producing one vowel was shown in S1's production of the word "refill". He seemed to intensify the high half-close unrounded front vowel /I/ and that was the only case that might not harm his speech intelligibility.

A similar case happened to $\mathrm{S} 2$. Although he often produced stacatto speech (disconnected speech) and that might affect the vowel quantity, the number of such case was too few to mention. Such case happened when he had to imitate the researcher's phrase "kissing dog", he uttered the phrase by disconnecting the two words with a rather long pause.

In conclusion, there was no significant points that affected the two subjects' speech intelligibility in the case of vowel quantity. It means that both subjects were found to be capable of pronouncing all English vowels with regard to vowel quantity.

\section{TABLE IV. VOWEL QUANTITY}

\begin{tabular}{|l|c|c|c|}
\hline \multicolumn{1}{|c|}{ Classification } & S1 & S2 & Examples \\
\hline Intensified $[\mathrm{I}]$ & 1 & $x$ & $/ \mathrm{ref} \mathrm{II} / \rightarrow$ [refirl $]$ \\
\hline
\end{tabular}

\section{E. Nuclear (tonic) Stress}

In relation with nuclear stress, table 4.37 below showed that both subjects were found to be capable of putting primary stress correctly, especially upon those one-syllable and twosyllable words. It was rarely found that both subjects were capable of pronouncing longer than two syllables because there were only a few three and four syllable words which were found. In this case, a matter of intelligibility could still be maintained.

TABLE V. NUCLEAR STRESS

\begin{tabular}{|l|c|c|l|}
\hline \multicolumn{1}{|c|}{ Classification } & S1 & S2 & \multicolumn{1}{c|}{ Examples } \\
\hline One-syllable Word & $\sqrt{ }$ & $\sqrt{ }$ & green, pen, big, fish, ten \\
\hline Two-syllableWord & $\sqrt{ }$ & $\sqrt{ }$ & window, happy, woman \\
0o & $\sqrt{ }$ & $\sqrt{ }$ & across, again, around \\
o0 & & & \\
\hline Three-syllable Word & $x$ & $x$ & usually, hamburger \\
Ooo & $x$ & $x$ & delivery, vacation \\
o0o & & & \\
\hline Four-syllable Word & $\boldsymbol{x}$ & $\boldsymbol{x}$ & education, unusual \\
o0oo & & & \\
\hline
\end{tabular}




\begin{tabular}{|l|c|c|l|}
\hline \multicolumn{1}{|c|}{ Classification } & S1 & S2 & \multicolumn{1}{c|}{ Examples } \\
\hline $\begin{array}{l}\text { Five-syllable Word } \\
\text { oo0oo }\end{array}$ & $x$ & $x$ & university \\
\hline
\end{tabular}

\section{V.CONCLUSION}

Referring to Jenkins' Lingua Franca Core, some facts indicated both shortcomings and weaknesses of the subjects in English sound pronunciation. First, the point of consonant inventory was noted to be incompletely reached by targets because of consonant deletion case. Second, the quality of consonant cluster was not thoroughly reached, either because of incompleteness of the cluster production although the number was too few to mention. Finally, syllable addition and reduction also ruined the thorough quality of word stress production. However, such drawbacks still led the way to intelligible speech with some notes upon their quality. All in all, compared to those which were already mentioned as weakness to reach decent intelligibility, both subjects were generally able to produce intelligible English speech, detailing either the consonants or vowels.

From the findings above, it was discovered that the two subjects had capability of producing their EFL speech sounds within the range of acceptable intelligibility. S1 was more fluent than S2 in pronouncing all types of consonants, except the affricates. In addition to that, the vowel production was similarly the same in results. Both subjects showed their capability of pronouncing all the vowel sounds. S2 was seen to be less fluent in front vowels and centring diphthongs production. Accordingly, it marked the strength of the two subjects in terms of their capability of pronouncing their EFL speech sounds despite their being autistic.

\section{References}

Alwiyanti, D. R. (2005). Kemampuan berbahasa Indonesia lisan pada T: Studi kasus seorang penyandang autisme pada pusat terapi dan tumbuh kembang anak "Permata Bunda” Surakarta (Unpublished S1 Thesis). Universitas Sebelas Maret, Surakarta.

American Psychological Association. (1994). Diagnostic and statistical manual of mental disorders, 4th Edition. Washington: APA.

Belkadi, A. (2006). Theory of mind and language deficits. SOAS Working Papers in Linguistics, 14, 3-13. Retrieved from https://www.soas.ac.uk/linguistics/ research/workingpapers/volume-14/file37813.pdf.

Dewi, C.M.D. (2014). Identifikasi kemampuan berbahasa anak autis di sekolah inklusif SD Negeri Giwangan, Yogyakarta (Unpublished Skripsi). Faculty of Educational Sciences Yogyakarta State University, Yogyakarta. Retrieved from http://eprints.uny.ac.id/14372/1/SKRIPSI_Des\%20Manin da\%20Chornelya\%20Dewi_10108241072.pdf

Genesee, F. (2009). Early childhood bilingualism: perils and possibilities. Journal of Applied Research in Learning, 2(2), 1-21.
Hughes, V. (2011). Cognition and behaviour: bilingualism doesn't hinder language. Simon Foundation Autism Research Initiative (SFARI). Retrieved from http://sfari.org/news-and-opinion/in-brief/2011/ cognition-and-behavior-bilingualism-doesnt-hinderlanguage-in-autism.

Indah, R. N. (2006). Proses pemerolehan bahasa: dari kemampuan hingga kekurangmampuan berbahasa. LINGUA Jurnal Ilmu Bahasa dan Sastra, 1(1).

Jenkins, J. (2009). The phonology of english as an international language. Oxford: Oxford University Press.

Kremer-Sadlik, T. (2005). To be or not to be bilingual: autistic children from multilingual families. Proceedings of the 4th International Symposium on Bilingualism p. 12251234 (Cohen, J., McAlister, T. K., Rolstad, K., \& MacSwan, J. Eds.) Somerville, MA: Cascadilla Press. Retrieved from www.lingref.com/isb/4/096ISB4.PDF

Pascoe, M. (2013). Speech intelligibility: how to evaluate and provide treatment. Retireved from http://www.apraxiakids.org/library/speech-intelligibility/

Rahayu, F. (2014). Kemampuan komunikasi anak autis dalam interaksi sosial (kasus anak autis di sekolah inklusi SD Giwangan Kotamadya Yogyakarta) (Unpublished S1 Thesis). Faculty of Educational Sciences Yogyakarta State University, Yogyakarta. Retrieved from http://eprints.uny.ac.id/42640/1 /12103244001_FITRI\%20RAHAYU.pdf

Spicer, E. (2011). The impact of Jenkins' lingua franca core on the teaching of pronunciation on CELTA and DELTA courses. Journal of Teacher Training and Development, 30. Retrieved from http://ihjournal.com/the-impact-ofjenkins\%E2\%80\%99-lingua-franca-core-on-the-teachingof-pronunciation-on-celta-and-delta-courses-by-eleanorspicer

Walker, R. (2001). Pronunciation for international intelligibility. English Teaching Professional, 21. Retrieved from https://englishglobalcom. files.wordpress.com/2013/12/pronunciation-forinternational-intelligibility2.pdf

Wells, K. L. (2004). The articulate voice: an introduction to voice and diction. New York: Pearson Education Group. 